\title{
The Effects of Multiple Sclerosis and Disease Modifying Therapy on Pregnancy
}

\author{
Tarneer Johal, BSc ${ }^{1}$ \\ ${ }^{1}$ Faculty of Medicine, University of British Columbia
}

\author{
ABSTRACT
}

Multiple sclerosis (MS) is the most common inflammatory condition of the central nervous system. Disease modifying therapy (DMT) aims to reduce relapse rates and decrease the quantity of lesions in the brain and spinal cord. Since MS is more prevalent in women than men, it is important to be aware of the interplay between MS and pregnancy. As MS can engender sexual dysfunction, primarily in the form of decreased desire and fatigue, it thereby affects conception. Hormonal differences between women with MS compared to women without MS include an increase in follicle-stimulating hormone and luteinizing hormone, and a decrease in testosterone. While fluctuations in estrogen result in a reduction in MS relapse rates during pregnancy, a subsequent increase in the post-partum period is observed. The mechanism of action and side effects of DMTs are described in this paper, including interferon, glatiramer acetate, and some newer medications. Although there are no recommended guidelines on the use of DMTs during pregnancy, it is generally agreed upon to cease their use prior to conception if possible, and the decision to continue a DMT should take into account the benefits to the mother and the risks to the fetus. Comprehending the mechanisms of action and teratogenicity indices of DMTs is crucial in understanding their effects on MS during pregnancy, which is an important aspect of providing health care to women with this condition.

$$
\text { RÉSUMÉ }
$$

La sclérose en plaques (SP) est l'affection inflammatoire du système nerveux central la plus commune. Le traitement modificateur de la maladie (DMT, de l'anglais) vise à réduire les taux de poussées et à diminuer le nombre de lésions au cerveau et à la moelle épinière. Comme la SP est plus prévalente chez les femmes que chez les hommes, il est important de reconnaître l'interaction entre la SP et la grossesse. Puisque la SP peut engendrer une dysfonction sexuelle, principalement en raison d'une diminution du désir sexuel et de la fatigue, elle affecte la conception. Les différences hormonales entre les femmes avec la SP et les femmes sans la SP incluent une hausse de I'hormone folliculostimulante et de l'hormone lutéinisante, et une baisse de testostérone. Bien que les fluctuations en œstrogènes entraînent en une réduction des taux de poussées de la SP durant la grossesse, leur augmentation subséquente lors de la période postpartum est observée. Le mécanisme d'action et les effets secondaires des DMTs sont décrits dans cet article, incluant l'interféron, l'acétate de glatiramère, et certains autres nouveaux médicaments. Quoiqu'il n'existe pas de lignes directrices sur l'utilisation des DMTs lors de la grossesse, il est généralement accepté qu'il faut cesser leur utilisation avant la conception si possible, et que la décision de continuer la prise d'un DMT devrait tenir compte des avantages pour la mère et des risques pour le fœtus. La compréhension des mécanismes d'action et des effets tératogènes des DMTs est essentielle pour apprécier leurs effets sur la SP durant la grossesse, ce qui constitue un aspect important dans la prestation des soins de santé aux femmes vivant avec cette maladie.

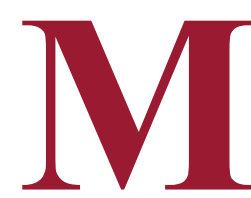

ultiple sclerosis (MS) is a common inflammatory disorder of the central nervous system (CNS) in which the myelin sheath is targeted and subsequently degraded. In MS, disease modifying therapies (DMT) aim to decrease the relapse rates and decrease the number of lesions in the brain and spinal cord. Several different types of DMTs exist with distinct properties and mechanisms of action. This is beneficial because the clinical course of
MS varies from individual to individual, and so treatment must be tailored to each individual's unique disease.

Since the proportion of women with MS is larger than that of men, the concept of managing MS with DMT while also taking into account pregnancy and fertility issues constitutes an important discussion. DMT may be useful for treating MS, but it can have negative effects on a woman if she is pregnant, trying

Keywords: Multiple Sclerosis; Pregnancy; Disease Modifying Therapy; Teratogenicity; 
to become pregnant, or has an unplanned pregnancy while on DMT.

\section{EFFECT OF MS ON PREGNANCY}

\section{Sexual Dysfunction}

The ability of a woman with MS to become pregnant is affected by her sexual function and desire. Sexual problems in MS patients have been organized into three categories: primary, secondary, and tertiary [1,2]. Primary problems refer to the direct neurological effect that MS has on the patient, including decreased sexual sensation, desire, and vaginal lubrication, as well as autonomic dysregulation and difficulties achieving orgasm $[1,2]$. Secondary problems refer to the physical changes producing an indirect effect on the patient, including fatigue and muscle weakness $[1,2]$. Tertiary problems refer to the indirect effect on the patient through emotional, social, and psychological mechanisms, including decreases in confidence and body image, increases in guilt and worry, changes in levels of perceived sexual attractiveness, and depression [1,2]. Although all levels of sexual problems negatively impact quality of life, secondary sexual problems have been found to have the largest influence on sexual dysfunction [3].

Several studies have informed our current understanding of the influencing factors and consequences of sexual dysfunction in women living with MS [1-5]. In 2006, a survey of 4,267 patients with MS living in the United States found that perception of body image worsened if the patient was less educated, female, had a longer disease duration, and a greater degree of disability [4]. Another study found that the number of sexual encounters per week was lower in women with MS compared to the general population [5]. These findings suggest that predictors of sexual dysfunction in women with MS are diverse and multifactorial.

The rate of sexual dysfunction is higher in women with MS than in the general population [6]. A study in Poland interviewed 137 women with MS to assess the women's neurological function [7]. It was found that $82.5 \%$ of patients suffered from at least one sexual problem, the most common complaints being decreased desire, arousal dysfunction, and orgasmic dysfunction [7]. In fact, another study has shown that sexual dysfunction has a larger negative effect on mental health than the severity of physical disability due to MS [8]. This detrimental impact on mental health is a concern to women who are, or who plan to become pregnant, as stress and depression can negatively influence a pregnancy and have adverse effects on the fetus.

Hormonal Effects

Endocrinological studies have shown differences in the levels of sex hormones and the gonadotropins that regulate their production between women with MS compared to women of the general population [9]. Significantly higher levels of folliclestimulating hormone (FSH) and luteinizing hormone ( $\mathrm{LH}$ ) have been recorded, as well as significantly lower levels of estrogen in the early follicular phase of the menstrual cycle $[10,11]$. This can have an adverse effect, as high FSH levels in the early follicular phase are correlated with a condition of low fertility known as impaired ovarian reserve $[10,11]$.

It has also been recorded that levels of testosterone in women with MS are significantly lower than in women without MS during the follicular and luteal phase [12]. Testosterone plays an important role in the repair of brain lesions and has protective effects against the autoimmune effects of MS [12]. The relationship between testosterone and severity of MS in women is seen in MRI studies, which show an inverse relationship between testosterone levels and the severity of brain lesions [13]. Based on this data, testosterone can be correlated with neuroprotective functions. In addition, an experimental study conducted in Iran in 2010 demonstrated that resistance training in women with MS helps to increase levels of testosterone while simultaneously decreasing cortisol levels, suggesting that exercise is beneficial in multiple ways for women with MS [14].

\section{Effect of Pregnancy on MS}

The rate of relapse in women with MS decreases significantly during pregnancy, but subsequently increases in the post-partum period. This is thought to be due to circulating hormone levels. In moderate concentrations, estrogens play a role in cell-mediated immunity, but in high concentrations, such as in pregnancy, estrogens have an anti-inflammatory role [15]. The protective effect that estrogens have on MS during pregnancy is currently being researched as a new treatment route. A pilot study showed a decreased number of enhancing lesions on $\mathrm{MRI}$ in women who were taking $8 \mathrm{mg}$ of estradiol per day compared to a pre-treatment baseline [16]. Other hormones, such as progesterone, are also being investigated as potential treatments for MS. One study examined the effect of progesterone on experimental autoimmune encephalomyelitis, which is the animal model of MS $[17,18]$. In this study, mice were given either a progesterone implant or a placebo treatment, and it was 
Table 1. Common disease modifying therapies used for patients with multiple sclerosis.

\begin{tabular}{|c|c|c|c|c|c|}
\hline $\begin{array}{c}\text { Generic } \\
\text { Name }\end{array}$ & $\begin{array}{l}\text { Brand } \\
\text { Name }\end{array}$ & Mechanism of Action & $\begin{array}{l}\text { Washout } \\
\text { Period } \\
\text { (months) }\end{array}$ & $\begin{array}{l}\text { Placental } \\
\text { Transfer? }\end{array}$ & $\begin{array}{l}\text { Use in } \\
\text { breast- } \\
\text { feeding? }\end{array}$ \\
\hline $\begin{array}{l}\text { Interferon } \\
\text { beta }\end{array}$ & Betaseron ${ }^{\circledR}$ & $\begin{array}{l}\text { Modulates the body's } \\
\text { immune response through } \\
\text { an unknown mechanism [9] }\end{array}$ & $0-1[23]$ & Unlikely [23] & Avoid [9] \\
\hline $\begin{array}{l}\text { Glatiramer } \\
\text { Acetate }\end{array}$ & Copaxone ${ }^{\circledR}$ & $\begin{array}{l}\text { Activates regulatory } T \\
\text { suppressor cells specific for } \\
\text { the myelin antigen [9] }\end{array}$ & $0-1[23]$ & Unlikely [23] & Avoid [9] \\
\hline Fingolimod & Gilenya ${ }^{\circledR}$ & $\begin{array}{l}\text { Prevents release of } \\
\text { lymphocytes from lymph } \\
\text { nodes [9] }\end{array}$ & $2[23]$ & $\begin{array}{l}\text { Crosses } \\
{[9,23]}\end{array}$ & $\begin{array}{l}\text { Avoid } \\
{[9,23,31]}\end{array}$ \\
\hline Natalizumab & Tysabriß & $\begin{array}{l}\text { Inhibits the migration of } \\
\text { leukocytes in the CNS by } \\
\text { binding against integrin [9] }\end{array}$ & $1-3[23]$ & $\begin{array}{l}\text { Crosses } \\
{[9,23]}\end{array}$ & $\begin{array}{l}\text { Avoid } \\
{[9,23,31]}\end{array}$ \\
\hline Mitoxantrone & & $\begin{array}{l}\text { Inhibits cell synthesis by } \\
\text { intercalating DNA and by } \\
\text { binding to DNA } \\
\text { topoisomerase II to prevent } \\
\text { replication of nucleic acids } \\
\text { [9] }\end{array}$ & $6[23]$ & $\begin{array}{l}\text { Unknown, } \\
\text { but likely } \\
{[9,23]}\end{array}$ & Avoid $[23,31]$ \\
\hline $\begin{array}{l}\text { Dimethyl } \\
\text { Fumarate }\end{array}$ & Tecfidera ${ }^{\circledR}$ & $\begin{array}{l}\text { Demonstrates anti- } \\
\text { inflammatory and } \\
\text { cytoprotective properties } \\
\text { through an unknown } \\
\text { mechanism [9] }\end{array}$ & $0-1[23]$ & Crosses [9] & Avoid $[9,23]$ \\
\hline Alemtuzumab & Lemtrada® & $\begin{array}{l}\text { Binds an antigen on T cells, } \\
\text { natural killer cells, and } \\
\text { monocytes, inducing their } \\
\text { lysis [9] }\end{array}$ & $3-4[9,23]$ & $\begin{array}{l}\text { Crosses } \\
{[9,23]}\end{array}$ & Avoid $[9,23]$ \\
\hline
\end{tabular}


found that progesterone reduced disease severity $[17,18]$.

\section{EFFECT OF DMT ON PREGNANCY}

A summary of the DMTs described in this article is outlined in Table 1.

Interferon (IFN)

Interferons (IFNs) are endogenous cytokines that modulate the body's immune response. Administration of IFNs or their analogues is a prevalent therapeutic modality in MS, though their effects on fertility and pregnancy are not fully understood [19]. In clinical trials comparing IFN therapy to placebo, IFN did not affect the rate of conception nor the rate of spontaneous abortion [20, 21]. However, IFN exposure was associated with a significantly lower birth weight and preterm birth [22]. The degree and significance of IFN transfer through breast milk has not been established, but it is suggested that IFN be avoided during breast-feeding [23].

\section{Glatiramer Acetate (GA)}

GA (trade name Copaxone ${ }^{\oplus}$ ) is a mixture of several four amino acid oligomers found in the myelin basic protein (MBP) sequence. It is thought to activate regulatory T-cells that recognize the myelin basic protein antigen. Similar to IFN, GA does not seem to affect the rate of conception nor the rate of spontaneous abortion when compared to women without MS, and no major concerns have been reported when GA has been used in pregnancy [22]. Women who have used GA during breast-feeding report no adverse effects, although it is still recommended to abstain from GA during lactation [24].

Fingolimod

Fingolimod (trade name Gilenya ${ }^{\oplus}$ ) acts to reduce the number of lymphocytes present in the central nervous system by preventing their release from lymph nodes. Rat experiments have shown no effect on female fertility upon administration of fingolimod, but they exerted teratogenic effects, the most common being congenital heart defects [9]. The rate of spontaneous abortion in women using fingolimod is higher than that of the general population [25]. Fingolimod has been confirmed to be excreted in breast-milk in rats, and is not recommended during lactation [25].

\section{Natalizumab}

Natalizumab (trade name Tysabri甲) is a monoclonal antibody against a subunit of the integrin molecule, thereby limiting the migration of leukocytes in the CNS. Although there are no studies of the effects of natalizumab on the fertility of humans, trials in guinea pigs have shown that high doses of natalizumab decrease fertility in females [26]. Reduced fetal survival and significant hematological effects have been seen in animal studies, as well as in children whose mothers took natalizumab in the third trimester of pregnancy $[9,27]$. Additionally, it has been well established that natalizumab is excreted into breast milk, and is therefore not recommended during lactation $[23,27]$.

\section{Mitoxantrone}

Mitoxantrone inhibits cell synthesis by intercalating between DNA bases and by binding to DNA topoisomerase II to prevent the replication of nucleic acids. The use of mitoxantrone in women has been linked to amenorrhea and a reduced ovarian reserve in multiple studies $[9,28]$. Furthermore, mitoxantrone has been associated with fetal growth retardation in rats, and has an increased rate of premature delivery in rabbits [9]. Although clinical trials have not been conducted in humans due to the overwhelming contraindications in animal studies, case studies have been reported where women have used mitoxantrone while pregnant. In one case, the use of mitoxantrone until 29 weeks gestation was associated with reduced fetal growth [29]. Due to the negative consequences of mitoxantrone in pregnancy, and due to its excretion into breast milk, its use is contraindicated in pregnancy [29].

\section{Dimethyl Fumarate (DMF)}

In MS, the mechanism of action of DMF (trade name Tecfidera ${ }^{\oplus}$ ) is not fully understood, but it is believed to have anti-inflammatory and cytoprotective properties. Studies in animals have not demonstrated a decrease in fertility with the use of DMF, but reproductive toxicity has been recorded [9]. Giving DMF to pregnant rats and rabbits during organogenesis resulted in maternal adverse effects and a low fetal weight; but in humans, DMF has not been shown to increase the risk of fetal malformations or the risk of spontaneous abortion [30]. It is currently unknown whether DMF is excreted into breast milk, and it is therefore suggested to refrain from its use during lactation [31].

\section{Alemtuzumab}

Alemtuzumab (trade name Lemtrada ${ }^{\oplus}$ ) is a humanized monoclonal antibody that reduces the number of CD52 containing T-cells, natural killer cells, and monocytes. Female mice who received alemtuzumab subsequently had decreased fertility and an increase in fetal mortality [9]. Alemtuzumab is also concern- 
ing because it can cause thyroid issues, which are especially a hazard in pregnant women, as hypothyroidism increases the rate of miscarriages and fetal malformations [9]. Therefore, the recommended washout period before conception is 3-4 months [23]. Excretion into the breast milk of mice has been reported, and although no information is available regarding excretion into human breast milk, it is advised to avoid alemtuzumab during lactation [23].

\section{CURRENT GUIDELINES}

Currently, there are no approved guidelines regarding DMT in pregnant women with MS. However, there are some generalized points that can be made. For each DMT, there is a minimum amount of time that the woman should be off the drug prior to conception [27,31]. This is called a wash-out period, and the wash-out periods for each drug are outlined in Table 1. Management of MS in the context of a pregnancy must take into consideration the benefits of the DMT to the mother, while keeping in mind the risks to the fetus. If the mother is able to cease her DMT without significant side effects, it is advisable to do so $[27,31]$. However, if the woman's symptoms are very severe, it may be necessary to continue the DMT during the pregnancy $[27,31]$.

The decision to continue a DMT during a pregnancy should take into account the severity of the disease, the benefits and risks of the DMT, and should entail multiple detailed discussions between the patient and the healthcare provider. However, due to the wide spectrum of disease activity and disease severity among women, there are unfortunately no accepted guidelines on the use of DMT in pregnant women with MS.

\section{CONCLUSION}

MS is a complex disease that exerts many effects upon a pregnancy, including sexual dysfunction and hormonal variations. In addition, pregnancy can influence the course of MS in a woman, including reducing the relapse rate intrapartum, and increasing the rate post-partum. Treatment for MS consists of DMT, of which seven different types have been briefly outlined. Although there are no accepted guidelines for the use of DMT in pregnancy, it is advisable to cease the use of DMT prior to conception if at all possible. Understanding the mechanisms of action and teratogenicity profiles of DMTs is important in understanding their effects on MS during pregnancy, which is a crucial aspect of providing health care to women with multiple sclerosis.

\section{REFERENCES}

1. Cordeau D, Courtois F. Sexual disorders in women with MS: Assessment and management. Ann Phys Rehabil Med. 2014;57(5):337-47.

2. Quinn H, Flood S, Mendelowitz E, Marrie RA, Foley FW. Predictors of fear of sexual rejection in individuals with multiple sclerosis. Sex Disabil. 2015;33(1):53-61.

3. Qaderi K, Merghati-Khoei E. Sexual problems and quality of life in women with multiple sclerosis. Sex Disabil. 2014;32(1):35-43.

4. Kolzet J, Quinn H, Zemon V, et al. Predictors of body image related sexual dysfunction in men and women with multiple sclerosis. Sex Disabil. 2015;33(1):63-73.

5. Gumus $\mathrm{H}$, Akpinar Z, Yilmaz H. Effects of multiple sclerosis on female sexuality: A controlled study. J Sex Med. 2014;11(2):481-6.

6. Lúcio AC, D'Ancona CAL, Lopes MHBM, Perissinotto MC, Damasceno BP. The effect of pelvic floor muscle training alone or in combination with electrostimulation in the treatment of sexual dysfunction in women with multiple sclerosis. Mult Scler. 2014;20(13):1761-8.

7. Lew-Starowicz M, Rola R. Prevalence of sexual dysfunctions among women with multiple sclerosis. Sex Disabil. 2013;31(2):141-53.

8. Schairer LC, Foley FW, Zemon V, et al. The impact of sexual dysfunction on health-related quality of life in people with multiple sclerosis. Mult Scler. 2014;20(5):610-16.

9. Amato MP, Portaccio E. Fertility, pregnancy and childbirth in patients with multiple sclerosis: Impact of disease-modifying drugs. CNS Drugs. 2015;29(3):207-20.

10. Grinsted L, Heltberg A, Hagen C, Djursing H. Serum sex hormone and gonadotropin concentrations in premenopausal women with multiple sclerosis. J Intern Med. 1989;226(4):241-4.

11. Shahdaeizadeh S, Edalatmanesh MA, Moghadasi M. Evaluation of sex hormones (FSH, Estrogen and Testostrone) changes during follicular and luteal phases and sexual dysfunction in women with Multiple Sclerosis. J. Jahrom Univerisity Med Sci. 2014;12(4):26-39.

12. Foroughipour A, Norbakhsh V, Najafabadi SH, Meamar R. Evaluating sex hormone levels in reproductive age women with multiple sclerosis and their relationship with disease severity. J Res Med Sci. 2012;17(9):882-5.

13. Tomassini V, Onesti E, Mainero C, et al. Sex hormones modulate brain damage in multiple sclerosis: MRI evidence. J Neurol Neurosurg Psychiatry. 2005;76(2):272-5.

14. Eftekhari E, Etemadifar M, Mostahfezian M, Zafari A. Effects of resistance training and vibration on hormonal changes in female patients with multiple sclerosis. Neurol Asia. 2014;19(1):63-7.

15. Airas L. Hormonal and gender-related immune changes in multiple sclerosis. Acta Neurol Scand Suppl. 2015;132(199):62-70.

16. Sicotte NL, Liva SM, Klutch R, et al. Treatment of multiple sclerosis with the pregnancy hormone estriol. Ann Neurol. 2002;52(4):421-8.

17. Tan IJ, Peeva E, Zandman-Goddard G. Hormonal modulation of the immune system - A spotlight on the role of progestogens. Autoimmun Rev. 2015;14(6):536-42.

18. Yates MA, Li Y, Chlebeck P, Proctor T, Vandenbark AA, Offner H. Progesterone treatment reduces disease severity and increases IL-10 in experimental autoimmune encephalomyelitis. J Neuroimmunol. 2010;220(1-2):136-9.

19. Arnason BG. Interferon beta in multiple sclerosis. Neurol. 1993;43(4):641-3.

20. Sandberg-Wollheim M, Frank D, Goodwin TM, et al. Pregnancy out-comes during treatment with interferon beta-1a in patients with multiple sclerosis. Neurol. 2005;65(6):802-6.

21. Sandberg-Wollheim M, Alteri E, Moraga MS, Kornmann G. Pregnancy outcomes in multiple sclerosis following subcutaeous interferon beta-1a therapy. Mult Scler. 2011;17(4):423-30.

22. Lu E, Wang BW, Guimond C, Synnes A, Sadovnick D, Tremlett H. Diseasemodifying drugs for multiple sclerosis in pregnancy: a systematic review. Neurology. 2012;79(11):1130-5.

23. Coyle PK. Multiple sclerosis and pregnancy presciptions. Expert Opin Drug Saf. 2014;13(12):1565-8.

24. Fragoso YD, Finkelsztejn A, Kaimen-Maciel DR, et al. Long-term use of glatiramer acetate by 11 pregnant women with multiple sclerosis: a retrospec- 
tive, multicentre case series. CNS Drugs. 2010;24(11):969-76.

25. Karlsson G, Francis G, Koren G, et al. Pregnancy outcomes in the clinical development program of fingolimod in multiple sclerosis. Neurology. 2014;82(8):674-80.

26. Wehner NG, Shopp G, Rocca MS, Clarke J. Effects of natalizumab, an alpha4 integrin inhibitor, on the development of hartley guinea pigs. Birth Defects Res B Dev Reprod Toxicol. 2009;86(2):98-107.

27. Fox RJ, Cree BA, De Sèze J, et al. MS disease activity in RESTORE: a randomized 24-week natalizumab treatment interruption study. Neurology. 2014;82(17):1491-8.

28. Lebrun C, Le Page E, Kantarci O, Siva A, Pelletier D, Okuda DT. Impact of pregnancy on conversion to clinically isolated syndrome in a radiologically isolated syndrome cohort. Multi Scler. 2012;18(9):1297-1302.

29. De Santis M, Straface G, Cavaliere AF, Rosati P, Batocchi AP, Caruso A. The first case of mitoxantrone exposure in early pregnancy. Neurotoxicology. 2007;28(3):696-7.

30. Li J, Gold R, Fox R, et al. Delayed-release dimethyl fumarate and pregnancy: Preclinical studies and pregnancy outcomes from clinical trials and postmarketing experience. Neurol. 2015;84(14):238.

31. Ghezzi A, Annovazzi P, Portaccio E, Cesari E, Amato MP. Current recommendations for multiple sclerosis treatment in pregnancy and puerperium. Expert Rev Clin Immunol. 2013;9(7):683-91. 